\title{
RETHINKING FILIPINO MASCULINITIES The Case of the Cosmopolitan Tambay
}

\author{
Joseph T. Salazar \\ Ateneo de Manila University \\ jsalazar@ateneo.edu
}

\begin{abstract}
In the Philippines, tambay refers to men who are notorious for hanging out in the streets for long hours owing to lack of formal work. Traditionally, representations of the tambay have revolved around drinking and the ironic display of patriarchal power despite the lack of clear contributions to the household economy. The study looks at the implications of transnational and economic shifts in rethinking the behaviors and attitudes of the tambay in Metropolitan Manila. The rising number of malls in the metropolis and the significant increase in dollar remittances from overseas have allowed for a shift in material and cultural practice, creating the need to simultaneously redefine and historicize this strand of Filipino masculinity. Aside from the new spaces they occupy, gender roles will be analyzed in relation to their relationships to the various women in their lives, and their socio-economic position will be reexamined anew bearing in mind the symbols of power and economic mobility available to them.
\end{abstract}

\section{Keywords}

consumption; gender representations; migration; mall; Palibhasa Lalake; remittance economies

\section{About the Author}

Joseph T. Salazar is an Assistant Professor at the Ateneo de Manila University. 
This study situates new identity formations in the Philippines through the appropriation of the term tambay, or bum, which has traditionally been applied to lower class men indulging in vices despite the lack of formal income sources. This paper has two sections, with the first examining numerous cultural constructions that account for shifting meanings to the concept. Focusing primarily on the ' $90 \mathrm{~s}$ TV series Palibhasa Lalake (Because They're Men), the tambay represented here is examined as an oppositional figure to dominant and Western constructs of masculinity. The symbol of the tambay sets out a discursive commentary on several labor and migration issues that surfaced during the sitcom's time. Keeping in mind the symbolic significance of Palibhasa's tambay, the second section examines the configuration of cosmopolitan middle-class men surfacing two decades later. Despite being caught in the same historic continuum of not being able to find work, they now frequent malls, shop, and are able to maintain a more seemingly comfortable and cosmopolitan lifestyle through remittances by relatives working overseas. Both cultural representations and case studies offer insight as to how a once decidedly lower class terminology can be relevant for mall-going men, their day-to-day routines, relationships, self-perception, and how they blend into the social environment of the mall, the city in which they live, and the transnational networks that have made the remittances financing their lifestyles, ultimately calling attention towards the arbitrariness of socio-economic classes, sexualities, and the problematic transnational character of Filipinos residing within the Philippines and overseas.

\section{CONTESTING MASCULINITY THROUGH THE TAMBAY}

Tambay is a relatively new word which evolved in the Philippines approximately in the last seven decades. It is derived from the English "stand-by" and is sometimes used as a verb which refers to hanging out usually in the context of drinking, set on the streets in front of a sari-sari store (literally "variety" store), which supplied provisions to communities prior to the arrival of convenience stores and supermarkets. Tambay is more popular as a noun and generally refers to men who have no work and pass the time indulging in drinks, food, and meandering conversations. It may also be used as a noun referring to the act of "hanging out" itself. Spatially, the term relegates the favored pastime of the patriarch at the fringes. While men who work are often forgiven for their vices, men unable to contribute to their households are often chastised and excluded. Both person and pastime echo sentiments towards passing guilt to the laziness of men. It is often used in the context of reinforcing a set of values critical in the performance of belonging, nationalism, and civic responsibility as it enforces the participation of men in economic activities as a way of asserting both their gender roles and civic

Kritika Kultura 33/34 (2019/2020): 860-882

(C) Ateneo de Manila University

<http://journals.ateneo.edu/ojs/kk/> 
duties. Even though all genders indulge in similar activities, the double standard is apparent in the dichotomizing language: men are described as tambays, while women are chismosa or gossipy. Despite the double standard, the consternation is much more critical towards men. Lately, however, the negative connotations attached to the word has delved deeper as it has acquired a sense of moral judgment over men who are jobless and whose time is wasted indulging in vices. Drinking is the most popular among them, but there is also smoking, gambling, womanizing, drugs, and-in the more Catholic mindset of some Filipinos-the consenting to sloth and the perpetuation of indolence.

Socio-economically, the tambay is often imagined belonging to the lower class. But many precedents have pointed out several contradictions to this stereotype as many men and even women have assimilated the term after losing employment owing to several possible reasons. Young adults now wear it as a badge of honor, glorifying the ability to hang out, indulge in alcohol, and do nothing as a rare privilege that not many can afford to do. In the Palanca award-winning novel Mondomanila, O Kung Paano Ko Inayos ang Buhok Ko Matapos ang Mahaba-haba ring Paglalakbay (Mondomanila, Or How I Fixed My Hair After a Rather Long Journey), Norman Wilwayco candidly describes the idealization of the tambay's lifestyle by an honor student graduating from the nation's top university:

Iba na talaga ang matalino. Hindi pa 'ko gumagradweyt, andami nang imbitasyong dumating sa 'kin. Galing sa iba't ibang kumapanya. Umano'y kailangan nila ng magagaling na mga engineer, tulad ko. Nang gumradweyt ako, summa. Marami rin akong nailathalang mga technical journal, thesis, at iba pang research paper na ngayon ay pinagkakaperahan ng mga buwakanang inang mga propesor at dean sa U.P. Isang buwan muna 'kong tumambay. Dapat kong namnamin ang buhay kalye. Puta, kapag me trabaho na 'ko, hindi na 'ko makakatambay. Saka mas masarap 'yung puro "I'll think about it" ang sagot mo sa mga imbitasyon ng iba't ibang kumpanya. Kumbaga, parang nagkakaroon ka ng alas. Nailalagay mo sila sa puwesto. Nawawala ang pagka-agresibo nila, nagmumukha silang tanga. (21)

It's hard being smart. I have been getting many offers even if I have yet to graduate. And from different companies, too. They said they needed good engineers like me. I graduated summa cum laude. I have also published a few articles on technical journals, theses, and other research papers that my fuckin' professors and dean in UP make money of. I hung-out for a month first. I need to make the most of street life. Fuck, once I have a job I won't be able to hang out. Besides it's good to say "I'll think about it" each time I get invited to join a company. It's like having an ace up your sleeve. You set them straight. They become less aggressive because they look stupid.

Kritika Kultura 33/34 (2019/2020): 861-882

(C) Ateneo de Manila University

<http://journals.ateneo.edu/ojs/kk/> 
The lifestyle itself becomes an assault to the status quo which conditions the prioritization of converting idle bodies into wage-earning laborers. In these instances, tambay becomes a term describing a lifestyle idealizing rare moments of rest and recreation that are not always available to the working class. It also becomes incursive towards the formal nature of institutions and the order that these institutions require. Since one's productivity becomes dependent on income, the denial by more able and more accomplished professionals to work speak of more stringent means of revising dominant historical processes that have resulted to a less than ideal status quo and power relations.

The term has also made it to politics in different ways. A group calling themselves "Ang Tao Muna at Bayan" have abbreviated their name to A TAMBay as they made a bid for party-list representation in the last national elections, possibly latching on the glorified meaning of the term now popular among the youth. Others have used the term to mock senators and congressmen whose non-appearance or lack of activity in their respective legislative sessions have earned them the ire of political observers. In recent years, the boxing champion and now Senator-elect Manny Pacquiao once led the list of so-called elected tambays notorious for not attending Congressional sessions when he was elected Congressman of Sarangani Province in 2010 and 2013. In this case, the tambay's negative connotations are revived, alluding primarily to the emasculation of a supposedly respectable group of men whose political ascent remains questionable.

Accompanying the tambay's shifting meanings are several constructions coming from popular culture. While there have been many representations that can be discussed, allow me to focus on the sitcom entitled Palibhasa Lalake (Because They're Men) directed by Johnny Manahan and which ran from 1987 to 1998. It remains to be one of the most visible representations of the tambay and the most transformative. Appearing during the period following Corazon Aquino's installation as president, the series first starred matinee idols Miguel Rodriguez, Richard Gomez, and basketball player turned comedian Joey Marquez. Here they acted out the roles of tenants in a boarding house ran by an aging woman played by Gloria Romero and her two daughters portrayed by actresses Cynthia Patag and Amy Perez. The story is a comical narration of problems confronting a band of educated young men coming from all over the country with a lower middleclass background as they search for work in Manila. Their time in the boarding house represents a period of hope and aspiration, where the hardships associated with having to share house are but temporary. Their attention is constantly drawn towards the prospects of finding more lucrative employment opportunities, secure ideal relationships, buy their own house, and start their own family. Palibhasa Lalake's men, however, fail to graduate from the boarding house. Except for the likes of Miguel Rodriguez and Apa Ongpin who have been written out of the 
storyline in order to pursue more lucrative careers outside of the sitcom, the men of Palibhasa Lalake multiplied. In the decade that they were in circulation, they have managed to recruit every rising actor, model, celebrity, and matinee idol possible to participate in their simulation of doing nothing, allowing the tambay's image to shift considerably in the decade or so that they were on television.

In terms of gender roles, contrasts between men and women are immediately apparent in the show: women are depicted to be more economically stable and financially reliable, while men are emasculated from their traditional roles not just as providers but also from partaking in the modern yet patriarchal norms that were upheld then. Surrounding the sitcom is a context charged with sociopolitical upheaval notable of which are the installation of the first female president in the country following years of turmoil under the Marcos dictatorship, the Asian financial crisis, and the exodus of workers overseas following Marcos's insistence on labor migration since the 1970s. What was supposed to be a temporary measure to offset increasing foreign debt slowly became the more convenient program as more and more government policies catered to an overseas employment program. In 1974, Marcos's Labor Code (Presidential Decree 442) prioritized this goal through the creation of agencies such as the National Seamen Board (NSB), Overseas Employment Development Board (OEDB), and the Bureau of Employment Services (BES) which all guided the propagation of a foreign worker industry in the country. All three offices were later consolidated under the Philippine Overseas Employment Agency (POEA) in 1982. If in 1975, Marcos saw the exodus of at least 30 thousand workers, the numbers increased more than tenfold in 1985 to at least 378,ooo. Meanwhile, local unemployment rates ballooned from 6.3 percent in 1972 to 12.55 percent in 1985. By the time Aquino assumed power, unemployment figures were at an all-time high, and the experience of narrating the tribulations of a relative, neighbor, or acquaintance who found work overseas became quite common that the idea of moving away became aspirational for many Filipinos. If in the beginning of her presidency, there were 378,214 workers deployed overseas, the number almost doubled to more than 615,00o in 1991 (POEA, cited in Brillo). Each succeeding president after Corazon Aquino will continue breaking that record within their respective terms.

Palibhasa Lalake runs narratives of men who are alienated not only by the economic success of workers deemed suitable for the demands of a foreign company, the sitcom is also a representation of men who are unemployable locally. Interrogating the self-worth of men against their traditional role as breadwinner, the show depicts Filipinos not readily able to assume the culturally idealized forms of manhood and yet continues to benefit from the institutions and systems inscribing male dominance. The show disrupts the hegemony of masculinity established by American media in the country which harkens back to white, well-mannered, 
Anglo-Saxon, English-speaking, and bible-touting gender constructs that are deemed most helpful in the enactment of modernity. In the absence of permanent work and the opportunity to buy a house, a car, and other provisions crucial in the staging of this kind of masculinity revolving around the breadwinner, Palibhasa Lalake repositions the tambay against a context of imminent failures.

On one level, there is the stigma of domesticity. Patriarchal attitudes prevail in looking at men spending time at home or in domestic confines as a form of failure even though men can also make contributions to improve living standards at home. Instead of eradicating perceptions towards domestic work, the prevalent attitudes in the sitcom still focus on diminishing being at home as a form of punishment or sanction against more socially accepted conventions regarding assuming the position of a breadwinner. On the other extreme, these conditions also reflect growing disparity between local, national, and international labor markets. In particular, it alludes to the lack of clear plan of employment by the government which continues to surrender some of its most potentially productive citizens to engage in work overseas that they are generally overqualified to do. It has been noted that

53 percent of employed Filipino emigrants have tertiary education schooled in humanities and social science (40 percent), education and health (30 percent), and engineering ( 26 percent). But only 14.5 percent are managers and professionals, with 26.6 percent working as technicians and clerks. The bulk of 60 percent are operators defined as service workers, agricultural workers, crafts workers, plant operators, and sales. In terms of economic sector, majority (53 percent) of Filipino emigrants are absorbed in the personal and services sector. (Zosa and Orbeta)

The tambay in Palibhasa Lalake marks a remarkable shift in migration practices emanating from the lack of widespread national welfare programs that have made the country rely more on overseas remittances, exacerbating the insecurity of men burdened with the economic responsibilities to provide for their family and alleviate them from poverty. For one, the generation of men as they have been depicted in the program reflect the predicament of a generation who has had more access to education than their predecessors (Cristobal). Literacy rates prior to World War I were a dismal 20\% and only gradually increased after the 1950 . Since the 1980 os, it has remained above 90\%. The Philippine National Statistics Office's 1994 Functional Literacy, Education, and Mass Media Survey (FLEMMS) even reports that in the same period, $88.29 \%$ of the population between the age of 15 to 24 years old possess not only reading and writing skills but also numeracy skills, which makes this generation have among the highest functional literacy rates in the Philippines (Ericta). Despite all these skills, education, and potential, many continued to struggle to find work as unemployment numbers continued to soar. 
The provocation of disappointment does not only apply to the engenderment of masculinity and its consequent demands on fulfilling the role of a provider, it is also constructed through the constant repositioning of these men in several hierarchies. Aside from being pitted against each other to compete for available work, the period also saw the same men being pitted against their wives, sisters, and even mothers. By this time, women have become more active in securing work. Aside from being pitted against fellow Filipinos able to secure work locally and overseas, their worth is also subject to comparisons with an infinite number of transnational identities whose specificity can no longer be ascertained but is believed to mar the competitiveness and employability of locals. Their lack of work has defined their gendered, racialized, and class-induced subordination, resulting to their use of masculinity as an instrument to obscure their marginalization.

What is also quite significant with Palibhasa Lalake is that it now assigns new representations to the tambay. If in the past, the stereotype of the tambay consisted mostly of men whose undesirability for lacking a stable job was represented and imagined through an abject physique, Palibhasa Lalake did the opposite by presenting the tambay as an educated man who cannot catch a break, and remains physically and sexually desirable. While the alienation from the economic systems represented by the OFW would position the Palibhasa man as counter-hegemonic, their tall, muscular, and physically desirable appearances coupled with the education they have received and their half-baked attempts to find work reinforce the hegemonic patriarchal power of men. This time, however, even though they may look the part, they are not performing the expectations that come with the role they assume.

With the likes of Gomez exuding the image of the perpetual bum on the TV show, the concept of the tambay was confounded further through an unrelenting display of libidinous spectacle. Helping in this regard is the constant portrayal of these characters as single men whose desire for any relationship takes a backseat to an unrealistic portrayal of economic independence. The sitcom is peppered with half-naked appearances featuring the latest boxer shorts or clothing that the actors are endorsing, brotherly affections that can be interpreted in a homoerotic manner, and the constant hailing of masculine superiority expressive of an idealized and eroticized aesthetic. Not only was the tambay being modified, its transformation happens at the expense of heterosexual masculinity, assaulting the traditional typology of the breadwinner as someone who disburses unnecessary effort. This unnecessariness can be traced to a series of historic shifts. First, the Industrial Revolution confronted hegemonic masculinities with the crisis of contracted physicality (Luciano). As more and more machines and technological innovations took over their occupational responsibilities, the need for brawn and hard labor diminished, paving the way for the blurring of boundaries between men and 
women at work. This historic narrative is propelled forward in Palibhasa where the boundaries are no longer blurred but have already been inverted. The assertion of masculinity can no longer be associated with strenuous work that was to be carried out by a rugged and virile figure, it is now being forced to adapt to the new dynamics provided by contexts where gender is antiquated.

The lack of clear romantic relations for all the male leads in the sitcom also contributes to the diffusing notions of the tambay. Their appearance not only conceals their inability to work, it also creates ambivalence towards their social status as perpetually single men. They jump from one new relationship to another and engage in romantic courtships with a string of female guests that change week after week in the program. While the male characters are portrayed to take the courtship process seriously, the women eventually grow wary of the men's shortcomings that lead to a break-up at the end of their short guest stint. The ever-shifting status of Palibhasa Lalake's characters from single to coupled and back again may express their inefficacy in marriage, but in no way diminishes their desirability as men constantly rewarded with a chain of female conquests.

Lending more complication to this representation of the tambay is how every major actor in the sitcom has been employed as product endorsers for numerous companies that marked the era. The clothing company Bench, owned by Ben Chan, is foremost as its reputation solidified alongside the popularity of its endorsers. Starting with Richard Gomez in the late '8os, he became one of the most prominent celebrities in the decade after. Capitalizing on the first wave of mall expansions in the early ' 90 os and the renewed popularity of media after being suppressed during Martial Law, Bench secured prime locations in every major mall and flooded media space with their advertising. Not only was Gomez visible during Palibhasa Lalake's Monday night timeslot on ABS-CBN, his commercials ran on primetime TV and radio. He made numerous appearances on film and was featured heavily in newspapers and magazines both as a celebrity, whose personal life was mangled publicly, and as a commercial model walking the runways and endorsing everything from Bench to Diet Coke to Bic ballpens. Gomez's many forays in media space experimented with different versions of masculinity, all of which reconfigured commerce in the determination of gender. Aside from antiquating gender, Gomez's images have resituated the practice of gender over determinants that were long considered unmasculine. In "The Making of the Self-Made Man," Kuchta reminds us of the "great masculine renunciation" when modesty and austerity became a determinant of masculinity by eighteenth-century British men especially when it came to fashion. The practice of simplicity became an emblem that warranted one's participation in power processes-especially in the political and economic arenas. Any man who had time to worry about their appearances and accentuated their extravagance especially in their clothing were 
deemed effeminate. The eighteenth-century aristocratic mores saw luxury as "the debased, debauched, and debilitating form of consumption that effeminated and impoverished England" (Kuchta 55). Shopping and participation in other leisurely comforts were to become a feminine pastimes, and men who were preoccupied with what they deemed to be tougher decisions for political policy and for economic expansion thought themselves too busy to participate in such frivolities.

Palibhasa's men are anything but simple and have been very ostentatious in reformulating their image both on and off the show. Aside from Gomez, Anjo Yllana, Randy Santiago, John Estrada, and the younger group referred to as "The Gwapings" (handsome young boys) composed of Jomari Yllana (younger brother of Anjo), Eric Fructoso, and Mark Anthony Fernandez were all added to the show and have also been in heavy circulation. Like Gomez, all of them modeled for Bench and were dispersed through images that invaded both public space through billboards and private spaces through television commercials airing repeatedly in living rooms. Not only were they comedians, they were also dramatic actors, models, TV hosts, recording stars, athletes, even politicians. Their images also struck audiences in intimate ways. By running a gamut of possible expressions of male identity-from the athletic to the rebellious to the homoerotic-they confounded the hegemonic representations of masculinity and became aspirational symbols codified in an ambiguous manner so that they may be desired and/or idealized by men and women alike.

Most of all these men represented a hybridity of masculinities. Whether they adhere to traditional views on men, or whether they are utilizing new forms of expression to particularize their respective identities self-consciously to break stereotypes, they have become influential in reimagining and obscuring other formations of masculinity allowing the likes of the tambay to be reinvented anew. Patterson and Elliott argue that that male representation in advertising and other visual media invert the male gaze, where men are more actively being urged to utilize their bodies to demonstrate their participation in highly privileged activities of consumption. The body no longer symbolizes their masculinity, it marks their renewed worth in a world where their traditional abilities have no consequence. Instead, they are forced to prove themselves through the constant transformation of their labor into access, entrenching the power of capitalism in contemporary lives.

The body-especially that of the tambay - has come to symbolize the projection of an identity rather than an identity on its own. It is visualized first and is invaded by the primacy of consumption. Even without work, men themselves are compelled to act as advertisements necessitating the ability to find a way to participate in the circulation of capital. Whatever identity they espouse are no longer grounded 
on conscious self-determinacy, they are now inscribed in a system of flows where the movement of products becomes more important than the movement and migration of people themselves. Mapping the influence of Gomez and his version of masculinity in the 1990s, the cultural critic Rolando Tolentino writes:

Ang narsisismong pagnanasa ng lalake ang tinutumbok ng mga ganitong ads.... Ang mga mata ni Richard sa ad ng Bench ay diretsong nakatitig sa mambabasa, tulad ng pagkatitig ng "The Eye" na imahen ni Hesus... Sa paraang hayag at tago, ang mga feminine na katangian ng mga ads ay nailalagay sa sekondaryong pwesto, naisasantabi, katulad ng bulaklaking disenyo $n g$ polo at $n g$ piano sa ad $n g$ Bench.... Ang modelo ay nililitratuhan na parang harap na harap sa mambabasa, halos masasalat mo ang mga tensyonadong kalamnan. At ang modelo ay may halataing distansya sa pinakamalapit na background upang ang fokus ay matuon sa modelo at modelo lamang, at sa produktong kanyang ipinagbibili. (21-22)

These ads exploit the narcissistic desire of men.... Richard's eyes in the Bench ad look directly at the reader, just like the image of Jesus's gaze in "The Eye”.... In both explicit and implicit forms, the feminine characteristics of these ads become secondary, even left out, just like the floral design of the polo shirt and the piano in the Bench ad.... The model is photographed as though he was in front of the reader, you can almost feel his muscles strain. And the model is significantly distanced from the nearest background to focus attention to the model and only the model, and the product he is trying to sell.

While it would be difficult to quantify, the reimagining of the tambay through Palibhasa Lalake becomes critical in reestablishing the disproportionate political and economic prospects of the ' $90 \mathrm{os}$. Notwithstanding all opportunities in education and mobility provided by their historic and contextual circumstances, the tambay reestablishes the constructedness of gender and its many contradictions and dynamics in the Philippines as part of an evolving global dynamic. It signifies a progressive disenchantment towards modernity whose implementation in the country has only resulted in the constant alienation of the population despite following all the prescriptions that were supposed to lead to national development and economic independence. This is evident in the reinvention of male identities, whose self-worth has been abandoned through their subjugation in a world dominated by commodity exchanges.

\section{THE COSMOPOLITAN TAMBAY}

To better understand the historical continuity of the gender issues represented through the tambay, allow me to shift attention to a couple of case studies 
showing the oppositional extremes of the concept. These case studies are part of a series of surveys, interviews, and observations gathered from interactions with the respondents from a longer and ongoing study about the mall and its role in reformulating Filipino middle-class nationalism around capital flows. While the original study from which these materials are drawn from focuses on the mall itself and its discursive implications about defining spatial practices in the Philippines, the current study focuses specifically on identity formation and the reformulation of masculinity in the country. This section articulates contemporary notions of the tambay through the examination of lifestyles and social relationships gathered from two men in their twenties living in Quezon City.

Jack, age 26 and the older of the two respondents, has a wife who works as a nurse in Saudi Arabia. He goes to the mall almost daily except for weekends when he claims that the volume of mall goers makes hanging out a bit more unbearable. He uses the mall as a place to conduct meet-ups for his buy-and-sell business which provides him a modest income to contribute to the family's finances. Paul, age 24, relies on remittances of his mother who has been working as a caregiver in Canada. Trying to finish a second undergraduate degree in Physical Therapy, Paul claims to live in the mall as he uses its numerous spaces invariably: the gym, the coffee shops to study, and as a general space to wander or pass time. These men frequent malls owing to the lack of permanent work, despite completing tertiary education, and rely primarily on remittances from relatives overseas. The succeeding discussion will highlight the way they construct their social identities in the context of shifting gender roles in an era of transnational consumption, and how these affect the issues of gender formation and identification discussed in the previous section. By examining narratives articulating their notions of self and self-worth, the section hopes to interrogate how the construction of masculinity at a personal level reflects the constructedness of gender, and how its possibilities have gone past individual experiences to a structural and systemic practice of enabling social stratification.

One notable problem is the issue of circulating masculinity both as a visual construct and its consequent embodiment within a series of transnational flows. In Masculinity, Media, and Their Publics in the Philippines, Cañete sees masculinity as the fulcrum calibrating the local effects of global economic activities. The use of globally recognizable commodities, images, and styles these men employ to construct their identities can simultaneously be regarded as the product of globalization and can be traced as part of a longer historic struggle that has seen production and labor as sites for contesting manhood. In this reading, the tambay in the television show Palibhasa Lalake and in masculinities that will be discussed here are consequences of reterritorializing Manila as a node in an increasingly complex capitalist market that has its origins in a colonial order. Under Spanish and American colonial rule, the Philippines could only offer agricultural produce 
for export. In exchange for goods such as tobacco, hemp, and sugar, Filipinos coveted luxuries, manufactured goods, and technology from the West. The consumption of Western products became crucial in lending adequacy to claims of the Filipino elite to being "modern." This is best exemplified during the American occupation when the diet was drastically changed as Filipinos situated in urban centers such as Manila developed a preference for processed food at the expense of fresh produce (Salazar). Despite an aggressive industrialization policy that favored import substitutions after the Second World War, Philippine retail spaces continued to be flooded with more and more imported commodities. Aside from food, media products - from print to music - have always found an audience in the country. The installation of the US bases created a demand for PX (post exchange) goods, the exodus of OFWs since the 1970s made duty-free shopping and hordes of other products from overseas more available, and the development of malls in the last three decades has helped in creating a frenzied atmosphere for newer and more different products. The Philippine's urban landscape has been physically and mentally invaded by shopping malls which have succeeded in reorienting the city's design to revolve around them. Key public transport hubs and business districts from Quiapo to Taguig have assembled around shopping centers offering each imaginable commodity for the elite, the working classes, and just about anyone who wants to participate in a culture of transnational consumption. In the last decade, malls have been developed as the showpiece for "self-contained cities" where retail, leisure, housing, and office spaces can be found in one building complex.

Whether such practices have evolved into a proper form of egalitarian prosperity has been subject to scrutiny. Inserting himself in this dynamic of architectural and socio-economic verticality, the tambay becomes a figure problematizing the aspirations to be part of the middle-if not the elite-class whose ascent is marked by consumption-driven activities. Unlike Palibhasa's tambay, whose reality is situated in the more interstitial moments between political upheaval and the consequent economic restructuring afterwards, the more contemporary tambays studied in this section are caught in a moment of sustained equilibrium where the dynamism of political change has dissipated and much of the economic conditions have normalized. More importantly, while the bodies of Palibhasa's tambay are aspirational, the actual bodies of the respondents in these case studies have become transformed into a form of capital that replicates aspirations of what is imagined to be ideal. In terms of their spatial positioning, they are more inclined to dispersing themselves within the more securely guarded confines of the city. Fewer job opportunities in the Philippines mean the spread of more tambays even in spaces where one least expects them. The mall becomes a critical space in redefining domesticity. Moreover, the stigma associated with the name also suggests more strategic and creative ways of circulating one's self in order to avoid 
scrutiny. The ability to conform to the circulated ideal body becomes a camouflage that conceals one's inability to perform the traditional role of the male breadwinner.

The first claim to the performance of masculinity, then, is how the body is dispersed in a network of commodities. With seven supermalls situated along EDSA alone (the main highway linking most of Metro Manila's major cities and municipalities) with a dozen other supermalls whose expansion is only constrained by the lack of real estate and countless other mall complexes, department stores, hypermarts, and supermarkets scattered throughout the metropolis-one's social mobility is often on display beside the stuff and the shops that contain them. Jack notes how the air-conditioning becomes an equalizing force in this race for commodities:

Lahat naman yata aircon lang ang dinadayo talaga. Pag nasa mall ako at konti tao, yung lamig talagang para bang nasa ibang bansa ka, parang may snow. Kaya kahit wala kang nabili, okay na din lang tutal nakaranas ka ng konting lamig gaya nung pakiramdam sa mga pelikula. 'Pag sa mall, hindi ako nakakaramdam ng pawis. Pinapawisan nga lang ako kapag napabili ng hindi ko dapat bilhin gaya ng sapatos, pabango, bag, T-shirt, damit. 'Pag nasa mall kailangan din ng porma. Dito ka lang makakapag-jacket nang todo-todo. Dito ka lang makakasuot ng shades kahit walang araw na pumapasok. May mga lalaki nga diyan anglalaki ng katawan pero naka-scarf.

People flock to the mall for the air-conditioning. When I'm in the mall and it isn't too crowded, it can get really cold as if you were in another country, like there's snow. It's fine even if you don't buy anything, at least you're able to experience cool weather you only get to see in movies. I don't sweat in the mall. I only sweat if I buy something out of impulse like shoes, perfume, bag, T-shirt, clothes. You have to look good in the mall. It's the only place where you can really wear jackets. Here, you can wear shades even if no sunlight comes in. There are some men who have fit and buff bodies who even wear scarves.

The mall sets up the fantasy of escape from the Third World tropics through a temperature-controlled space that is quite distinguishable from the heat outside. Because no one is turned away from taking advantage of a mall's air-conditioning, patrons are left to construct and reinforce their own respective illusions of who they are or who they want to be through expressions of their image.

Unfortunately, expressing one's self can be very expensive and not everyone can afford to experience the best of what malls can offer. Asked where the feeling of guilt comes from for buying more, Jack explains: "Wala akong trabaho. Umaasa lang naman ako sa padala ng misis ko. May sideline ako pero kulang pa yun para pakainin ang sarili ko. Hobby lang yun, patingi-tingi ang kita. (I have no work. I only rely on the money my wife sends. I have a sideline but it is not enough to 
feed myself. It's just a hobby, there's hardly any profit)." This sideline consists of scrounging through Japanese surplus goods that have popped up all over the city, looking for things to sell. His favorite digs are the surplus stores in Novaliches, located at the northern edge of Quezon City bordered by the province of Bulacan. It is a half hour drive from where he lives and here he spends an hour or so looking for things that can be advertised on Facebook antique groups for a higher price. He describes his best purchase as a set of kabuki dolls he bought for three hundred pesos which he sold to a collector for more than eight thousand. Most of the time, however, he considers himself fortunate to earn enough to sustain what he deems as a hobby, cover his gas and lunch money, and buy a few things every now and then in the mall.

Surprisingly, Jack never saw this kind of business as a legitimate source of income. For him, work had to be conducted in a more formal environment dominated by cubicles and computer terminals where a regular paycheck can be made and government-mandated benefits such as health care, pensions, or housing loans can be readily availed. Having graduated with a business degree and worked at a couple of BPO companies before, his idea of a suitable profession has been anchored on the image of belonging in structured organizational work expressive of a civic performance. In this kind of work, attention is given to an individual's participation in a social unit and how they are able to contribute to various areas of development in order to justify the protection and liberties afforded to them by the state. Giddens describes this process of belonging as central to the experience of modernity warning us that

Modernity is a double-edged phenomenon. The development of modern social institutions has created vastly greater opportunities for human beings to enjoy a secure and rewarding existence than in any type of pre-modern system. But modernity also has a sombre side that has become very important in the present century, such as the frequently degrading nature of modern industrial work. (7)

The idea of partaking in opportunities and benefits outweighs the regulated nature of labor associated with modernity. Jack compromises the absence of regimented work with an outward appearance of a yuppie. His shopping preferences lean towards smart casual clothes, leather shoes, and a fondness for coffee shops and mid-range restaurants for meeting his buy-and-sell clients, asserting that such an appearance legitimizes his presence in the mall:

Siyempre ayokong magmukhang kanto boy o tambay. Ang dami na 'nun sa mall, gusto ko magmukhang parang may trabaho ako. Classic pa din ako. Nagbabalat akong sapatos, nagsusuot ako ng slacks, at laging clean cut. Malaki din tulong nun sa buyand-sell ko, akalain mo. 'Pag pumupunta akong casual lang at mukhang walang ibang 
pagkakaabalahan, ang lakas tumawad ng kausap ko. Pakiramdam nila, desperado ako. 'Pag ang bihis ko mukhang galing opisina, hindi sila malakas tumawad, iniisip yata nila "hindi nito kailangan ng pera," o kaya "hindi nito pakakawalan nang basta-basta ang benta niya."

I don't want to look like a vagrant. There are lots in the mall, so I like to look like I have work. I consider myself to be classic. I wear leather shoes and slacks, and I am always clean cut. It helps my buy-and-sell, imagine that. When I appear in casual clothes and have nothing else to do, the people I transact with ask for large discounts. They think I am desperate. When I show up like I came from an office, they don't ask for discounts. They probably think "he does not need money," or "he won't let go of his goods that easily."

Like the hierarchies he assigns to clothes, the worthiness of his buy-and-sell business is measured against the imagined supremacy of work valuing accumulation and reproduction. While the self-contained "city" whose operations are anchored on the mall would seem to present a symbol of overcoming industrial production, it also represents the disappearance of the center, capital, and nation. It has paved the way for systems of speed and instantaneity-where products and capital move faster while human passage and imagination remains at a standstill in constrictive office cubicles, in traffic, in immigration lines and queues for visa applications, and in that all-too-familiar feeling of trying to go somewhere but never really leaving one's place. Stasis becomes an overarching attribute that connects the immobile male to the deterritorialized nation/state. Jack is only afforded limited movement and his own mobility is overpowered by more transcendent cultural objects. Since there is so much to abhor in office work, Jack admires it, choosing to construct his life and his gender identity around the non-existent work he idealizes.

Besides style preferences that reflect work aspirations, his static position is further confounded by his relationships to several female OFWs. Jack's wife's decision to find work abroad has always been a source of tension between the couple and also between their relatives and friends who express consternation to Jack's lack of work as a trait unbecoming of a man. Jack's college education was paid for by an aunt who once worked as a singer in Hong Kong and they have always expected him to pay this back by helping the extended family more. His wife, on the other hand, has an older sister who is still working in Australia as a nurse. Jack says the older sister was very influential in convincing his wife early on to take up nursing and to go overseas for work. He feels his mother-in-law's resentment for not being able to provide a more comfortable and secure life for her daughter. But even more painful for Jack is how the long-distance relationship with his wife has left him wrestling with so many insecurities: 
Ako yung lalaki tapos ako yung pinapakain ng asawa ko. Nakapagtapos naman ako $n g$ business. Nung nagtatrabaho ako, hindi naman ako laging late at hindi ako sakit ng ulo sa boss, masunurin ako. Kahit paano, may hitsura naman ako. Hindi ko alam kung bakit hindi ako makakuha ng trabaho. Gusto ko sana ang misis ko na lang ang nandito at ako na lang ang nakikipagsapalaran sa labas. Madami din naman kasing kuwento sa mga OFW sa ibang bansa na kahit may tiwala ka sa asawa mo, hindi mo maiwasang isipin kung paano kaya siya.

I am the man but I am being fed by my wife. I finished a business degree. When I worked, I was not always late and I did not give my boss any trouble, I was obedient. I know I look good, too. I don't understand how I cannot get a job ever since. If I had my way, I would want my wife to stay here and I'll be the one to work overseas. There are lots of stories about OFWs that even if you trust your spouse, you can't help but think about how they're doing.

Stasis is not just rendered by the onslaught of moving commodities and flowing capital, it is also expressed through gender constructs imposing hierarchies between males and females, heterosexuals and queers, and even between transnationals within a wider cross-section of globally determined and hierarchized labor. Money sent by OFWs in 2014 reached US $\$ 26.92$ billion, making the Philippines the world's third largest recipient of remittances behind India and China ("Where \$26.92B"). From the early 1990s, feminized work has the most sought-after labor export from the country, comprising an average of 55\% of all OFWs (Hochschild). The year 1994 saw the largest exodus of women at 60\%, two-thirds of whom found employment as caregivers, domestic helpers, entertainers, and other forms of work abandoned by women in postindustrial nations who have opportunities to take on non-domestic responsibilities (Barber). As for men, career prospects are not as rewarding. Since the 1970s, seamen and engineers have been the most lucrative work for men. In 2014, remittances from seafarers amounted to $\$ 5.6 \mathrm{~B}$ of the $\$ 26.92 \mathrm{~B}$ total, or at least $20 \%$ (“Where \$26.92B"). Although the proportions have decreased considerably by 2015 where there were $51.1 \%$ females compared to $48.9 \%$ males, the women are getting younger and younger compared to men ("2015 Survey"). According to the same report, 7 percent of female OFWs were between 15 to 24 years old, and $29.5 \%$ were between the ages 25 and 29 as opposed to men who only comprised 6.8 and $21.9 \%$ of the respective age groups, and where more than half of the females were laborers and unskilled workers. Working at a younger age, women enter the international workforce with less education and experience, potentially also earning less income than men, thus contributing to the reduction of costs of personal consumption and reinforcing the privilege of the wealthier economies' citizens and collective society.

However, many domestic workers also come from the middle-classes who are forced to enter the global market. Women who provide transnational labor 
represent a modulated version of globally influenced desires for social mobility, consumption, and accumulation. Their exploration of work in the transnational circuits are also the result of retrenchment, lack of jobs, and declining incomes (Parreñas). Despite the seeming demotion of social status, their employment provides security or upward social mobility for their families. Many employers find women ideal not just for their low labor rates but also subservience brought about by desperate economic conditions back home, making them more susceptible towards abuse. This demonstrates how transnational labor flows are created alongside the maintenance of gender hierarchies. In many of the contexts where these vulnerable Filipinas find work, numerous and varying gendered ideologies and social relations are utilized to discipline them. The practice is not novel. European colonial labor practices have always relied on the "recruitment of women (particularly young unmarried women) as ... domestic servants and concubines to colonial officials or as family workers on plantation estates" (Mills 42). The practice is being perpetuated through the codification of workers through their nationalities. In the early 1990s, when word got around that a respected dictionary listed Filipinas as synonyms of house maids, outrage reflecting the nation's hypersensitivity towards the image of the OFW ensued.

Even though these representations position Filipinas in the lowest ranks of a transnational hierarchy, Filipinas still find themselves embedded in this global hierarchy of gendered labor while Filipino men like the ones in Palibhasa Lalake remain at a loss as to how inject themselves in the transnational labor market. Recognizing this limitation in prospects for men, Paul has taken a second undergraduate degree in Physical Therapy in the hopes of following his mother to Canada where she works as a caregiver. Earning his first degree in Communications, Paul once worked as a production assistant in one of the major networks earning a salary of around 8,00o pesos monthly. Seeing older men who had a similar educational background and professional interests go nowhere, he knew his future in the network was not promising:

May kaibigan po ako doon, mag-aapat nang taon na walong libo suweldo nang pumasok ako. Kuwento po niya sa akin, labing-isa silang pumasok na PA (production assistant)-tapos may mga kasabay pa siyang mga OJT na hindi din naman binabayaran, binibigyan lang ng grade. Pero sa dinami-dami nilang pumasok noon, siya na lang daw po natira. Wala ni isa daw sa kanila ang napermanente sa trabaho. Dahil siya na lang daw po naiwan, baka naman makapasok na siya sa ibang department. Sa loob-loob ko lang, hindi ko lang po masabi sa kanya, hindi 'yan mangyayari! Hindi' 'yan madadaan sa hard work lang, palakasan diyan.

I had a friend who stayed, he started four years before me and his salary never increased from eight thousand pesos. He told me, he was part of a group of eleven 
production assistants when he came to work there along with a number of on-the-job trainees that were never paid but were only given a grade. All of them left except for him. No one was regularized. He was hoping that because he was the last one that they would transfer him to another department. In my head, because I did not have the heart to tell him, it will never happen! They will never reward hard work, you need to know people!

Originally, his relatives wanted him to take Nursing but he took Physical Therapy as a compromise in the hopes of finding possibilities outside of medical care. Despite this, a second degree is proving to be more difficult than he has anticipated. While his mom is expecting him to finish in the next two years since he is already on his third year of studying Physical Therapy, he has only completed barely a year's worth of credits.

Naghirap na ako minsan, pero take two na po ito, aral na naman ako. Kaya 'pag sinusuot ko po yung uniform namin sa school, asar na asar po talaga ako. Mukha po kasi akong nag-aaral ng nursing o medicine tapos lagi pa po akong nababati ng mga kapitbahay namin. Sabi nila, "Aba, nagdodoktor ka na pala?” Noong una, ipinapaliwanag ko pa po yung situation ko, na second degree ko na po ito at walang connection ang una kong degree sa inaaral ko ngayon. Pero nakakapagod na nakakaasar po e. Parang everyday na lang ipinapaalala sa akin na nagkamali ako.

I already suffered once, and here I am, studying for the second time. Each time I wear our school uniform, I feel cross. I look like a student from nursing or medicine and our neighbors would talk to me. They'll say, "Oh, you're going to be a doctor?" At first, I would explain my situation, that this is my second degree and what I studied before has nothing to do with what I am studying now. But it's tiring and annoying. It reminds me everyday that I made a mistake.

Unlike Jack who anchors his masculinity in more traditional (his term is "classic") and stereotypical images of nine-to-five office work and outfits, Paul has embraced more unconventional appearances. On the surface, there is the use of non-conformist clothes as he actively purchases design featuring frayed fabrics, dull colors, and an alternative aesthetic that goes against the grain. The acceptance of a future anchored in caregiving work-which he considers non-masculine-is indicative of one of the harder compromises he has made in order to secure his future financially. Such compromises are reflective of an increasing number of male OFWs who have taken on work more conventionally associated with women such as nursing, caregiving, and teaching. Numbers from the Philippine Overseas Employment Agency have seen the ratio between male to female unskilled workers move from 1 man for every 13 women in 2004 to 1:7 in 2011. 
While the willingness to adjust to transnational labor demands represent more opportunities for placement, it also embodies the reconfiguration of identities for the men forced to take on such changes. Because there is an acknowledgement that his mobility is hinged on letting go of the aspirations he once held in esteem, Paul is struggling with how to place his masculinity. Escaping the torment of school, house and neighborhood, the mall represents the only space where he can hold on to his self-identity, wearing the clothes he prefers and avoiding wearing uniforms and responsibilities he is not willing to take on:

Sino ba namang lalaki ang gustong magtrabaho bilang caregiver? Ngayon nga lang, yung lola ko hindi ko mapagtiyagaaan, what more kung 'di ko po kamag-anak? Parang nakakatakot isipin na gano'ng trabaho lang ang puwede kong gawin. Kaya 'eto, nagbubulakbol. Patambay-tambay sa mall. Alam kong patapos na ang maliligayang araw ko at magiging miserable na ako. Kaya kahit po walang pera o walang mabili, iikotikot lang ako, titingin-tingin. Pag-iisipan ang mga puwedeng pag-ipunan.

What man aspires to become a caregiver? I have no patience even for my own grandmother, what more if I need to care for someone not related to me? It's scary to think that this is the only work I can do. Maybe this is why I rebel or act out. I hang out in the mall. I know my days are numbered and misery is inevitable. Even if I have no money or nothing to buy, I'll go and look around. I'll think about what I can save for what to buy next.

Aside from becoming a node of transnational economic exchanges, the mall becomes the setting for where crises of masculinity are acted out. Having no options for work or opportunities to advance their interests professionally, men left behind by spouses, partners, and relatives in the Philippines find themselves renegotiating their authority at multiple fronts. The inability to work also signals their inability to function as breadwinner, since their decisions are often ignored or challenged by the other members of the household. On one level, monetary concerns are always a source of tension within the family. Paul's second college degree has always been a source of tension as it has incurred more expenses than anticipated. Paul explains:

Lumaki po kasi akong wala si mommy sa bahay kaya may kanya-kanya po silang style sa paggawa ng decisions lalo na kung tungkol sa akin. Si lola po kasi, medyo strict. Kapag kailangan ko po noon magpaalam para gumimik, iiwasan ko po siya. Hindi ako magpapaalam sa kanya kasi laging no ang sagot niya sa akin. Doon po ako sa daddy ko nagpapaalam, siguro mas naiintindihan po niya generation ko at ang mga needs ko bilang guy. Pero 'pag problem sa school, kay lola po ako lalapit, kasi si daddy medyo takot kay mommy, at sensitive siya sa sasabihin ni mommy kapag may ginawa akong hindi maganda. Ngayon pong matanda na ako, mas magulo na. May gusto po akong 
gawin, may ibang gustong mangyari sa akin si daddy, may ibang gustong mangyari si lola, may iba ding gusto si mommy. Sa loob-loob ko lang, kung maganda lang po sana work ko, siguro makakagawa ako ng decision ko. Iba pa din talaga ang pride kapag may sarili kang pera, may choice $k a$.

I grew up without my mother at home and the rest of the family have had their own style of making decisions especially concerning me. My grandmother is a little strict. If I need to ask permission to go out with friends, I try not to ask her permission. I don't ask her because she always says no. I ask permission from Dad, I guess he understands my generation more and my needs as a man. But if I have problems at school, I go to my grandmother because my dad fears my mom, and he tends to take my mom's word more personally if I do wrong. It's more chaotic now that I'm old. If I try to make a decision for myself, my dad, grandmother, and mom will have different opinions. If my work was better, I could probably make decisions for myself. There's a certain pride when you earn enough to support yourself, you have choices.

The choices Paul speak of do not only implore activities that allow for the mobilization of class and capital, but also losing sight of the display of prowess through traditional forms of work regarded as masculine. The problem is complicated further by the lack of control they have over the movement of their female loved ones. While women work and are able to transcend the many restrictions of going overseas, many men feel more and more confined into domestic spaces and find themselves with nowhere else to go but the mall. Fiske once contended that the mall offers a space for the empowerment of women, offering them escape from the confines of male-controlled domesticity. But the mall is a refuge for men, too, especially if they are unable to confront responsibilities at school, work, or home. While school and work provide a natural setting for scrutiny and competition, the absence of mothers, wives, daughters, and other family members who contribute substantially to the family income has also transformed many roles and responsibilities up for grabs in homes themselves. For the two respondents, their homes remain female as dominant matriarchs and mother figures assume control over domestic decisions. Jack acknowledges this emasculation. Once a provider who stood as the head of the household, he admits that:

Noon, hindi ako mautusan magbayad ng bills o bumili ng suka sa tindahan. Ngayon, lagi akong inaabutan ng pera at wala nang tanong o pasabi, basta nakapatong na lang sa mesa ang dapat bayaran at ang pambayad. Ni hindi na sila nagtatanong kung may gagawin ba ako, basta na lang abot ng pera 'pag kailangan tumakbo sa tindahan o sa grocery. Parang messenger na lang ako. Simula nga nang mag-abroad ang misis ko, hindi na nila ako tinatanong sa bahay kung ano ang gusto kong kainin. Noong nariyan naman siya, at kaming dalawa nagtatrabaho, laging tinatanong ng mama niya [his mother-inlaw] kung ano gusto kong baunin kinabukasan o kung ano gusto ko kainin pag-uwi. Pati 
katulong namin, nagtatanong noon kung ano gusto ko. Ngayon, nariyan na lang lagi ang pagkain sa mesa. Pinagtitirahan naman nila ako kung mahuli ako ng uwi, pero hindi na nila ako tinatanong kung ano ang gusto ko.

Before, no one dared ask me to run errands, from paying the bills to buying vinegar from the neighborhood store. Now, they just hand me money without even asking, they put the bill on the table and the money for it. No one bothers if I have something else to do, they'll just give me the money if they need something for the store or grocery. I feel like a messenger. Since my wife worked overseas, no one asks me now what I want to eat. When she was here, and both of us worked, her mother kept asking what I wanted to take with me for lunch the next day. Even our maid asks me back then. Now, the food is just there on the table. They leave food for me when I get home late, but no one asks me what I want to eat anymore.

Aside from providing refuge for men who have lost control in their own homes, the mall also provides a setting for men to reimagine global space while investing on their bodies. Unable to travel, the mall becomes an extension for the relatives and loved ones left behind and isolated from their own domestic spaces. Through it, they not only gain exposure to trends, products, and ideas useful in enhancing their masculinities, they are able to appropriate the space as their own. Despite seemingly futile, the constant renegotiation of the mall as one's personal domain becomes critical in negotiating subjectivity. The coercion of people to invest time and energy into their bodies to uphold their social status has indicated an interesting shift in the objectification of masculinity as commodities are now utilized to produce bodies, rather than bodies producing commodities. Lefebvre frames this aspect of spatial construction devoid of the logic of space and time as a contemporary abstraction. As the space of bourgeois capitalism, the commodification and subsequent subversion of space obscure real relations between people in favor of upholding relations under symbols and metaphors. Whether it is Jack's office for his makeshift buy-and-sell business, or Paul's retreat from school and home, the mall becomes that one refuge maintaining illusions of the self, or versions of the self that one can live with.

\section{CONCLUSION}

The tambay, which once served as a construct to flag down lower class men to call attention to their lack of civic contributions, has now morphed into a gender construct situating Filipino men dependent on foreign remittances in a more expansive network of transnational socio-economic relations. The late 1980 os first saw this shifting pattern of gender roles. As more and more Filipinas started to gain 
employment in the international job market, more Filipinos have been left to deal with declining authority over both professional and domestic decisions affecting not just their economic standing as breadwinners but also their relationships. While the feminized economy represents an interesting shift in women's employability, it also does not bode well for the overall financial capacity and social relationships of the Filipino household which has been undergoing tremendous stress renegotiating gender roles since the $1980 \mathrm{os}$. On the economic front, the work that most of these women do are not only unideal, they also undermine the qualifications of these women who have a common history of struggle to put themselves to school. Socially, they are also alienating themselves from their families.

While men may pick up the slack of restructuring domestic relations at home, prevalent attitudes regarding gender continuously stress that they are still the breadwinners. The representations in sitcoms such as Palibhasa Lalake barely scratch the surface, and the pressures they confront now need to be directed towards policies that allow us to imagine gender roles not just differently, but more flexibly. How do we provide men with more work? What roles can they adopt, and how can the existing institutional infrastructure help in shifting attitudes towards gender and its existing stereotypes? While these revisions of masculine identities seem to push men into further isolation, it does present opportunities for reconstructing the self. For one, it allows more room for the exploration of new work opportunities outside traditional expectations that have burdened them. Jack's buy-and-sell business is a start. And while he does not see the profitability of such an enterprise now, it does mark the beginning of a number of internet-based ventures where economic opportunities can be realized-ride-sharing applications providing alternative work for men such as Grab come to mind. Further research on these ventures and their economic and cultural impacts especially on identity can be examined in future studies. No matter how these new gender constructs are interpreted, they speak of the arbitrary notions of gender, socio-economic classes, and other ideas pertaining to being Filipino.

Cultural and historic texts have originally reiterated the tambay's isolation from Philippine society. However, contemporary incarnations have seen a growing number of men related to female OFWs recast questions not only on the terminology but also the nation's precarious position in a world driven by transnational capital flows. 


\section{Works Cited}

"2015 Survey on Overseas Filipinos." Philippine Statistics Authority, 18 May 2016, https:// psa.gov.ph/content/2015-survey-overseas-filipinos-o. Accessed 21 June 2016.

Barber, Pauline Gardiner. “Agency in Philippine Women's Labour Migration and Provisional Diaspora." Women's Studies International Forum, vol. 23 no. 4, 20oo, pp. 399.

Brillo, Bing Baltazar C. "Path Dependence, Increasing Returns, and Philippine Labor Migration Policy." Crossroads: The ASA Journal, vol. 8, no. 1, 2008, pp. 24-61.

Cañete, Reuben R. Masculinity, Media, and Their Publics in the Philippines: Selected Essays. U of the Philippines P, 2014.

Cristobal, Len. "Literacy in the Philippines: The Story behind the Numbers." Literacy Worldwide, 6 Aug. 2015, https://www.literacyworldwide.org/blog/literacydaily/2015/08/o6/literacy-in-the-philippines-the-stories-behind-the-numbers. Accessed 1 Feb. 2019.

Deleuze, Gilles, and Guattari, Felix. A Thousand Plateaus: Capitalism and Schizophrenia. U of Minnesota P, 1987.

Ericta, Carmelita. "The Filipino Youth: A Statistical Profile." Paper presented at the Fifth National Social Science Congress, Philippine Social Science Center, Diliman, Quezon City, Philippines, 15-17 May 2003.

Fiske, John. Reading the Popular. Routledge, 1989.

Giddens, Anthony. The Consequences of Modernity. Polity, 1991.

Hochschild, Arlie R. "Global Care Chains and Emotional Surplus Value." On the Edge: Living with Global Capitalism, edited by Will Hutton and Anthony Giddens, Jonathan Cape, 200o, pp. 130-146.

Koltz, Hattie. "Doctors Offer Alternative, Naturally: Naturopathic Doctors Meet Growing Demand for Their Services." Ottawa Citizen, 17 May 2008, H1o.

Kuchta, David. "The Making of the Self-Made Man: Class, Clothing, and English Masculinity, 1688-1832." Sex of Things, edited by Victoria De Grazia and Ellen Furlough, U of California P, 1996, pp. 54-78.

Lefebvre, Henri. The Production of Space. Translated by Donald Nicholson-Smith. Blackwell, 1991.

Luciano, Lynne. "Muscularity and Masculinity in the United States: A Historical Overview." The Muscular Ideal: Psychological, Social, and Medical Perspectives, edited by J. Kevin Thompson and Guy Cafri, American Psychological Association, 2007, pp. 41-65.

Mills, Mary Beth. "Gender and Inequality in the Global Labor Force." Annual Review of Anthropology, vol. 32, 2003, pp. 41-62.

Parreñas, Rhacel S. Servants of Globalization: Women, Migration and Domestic Work. Stanford UP, 2001.

Patterson, Maurice, and Richard Elliott. "Negotiating Masculinities: Advertising and the Inversion of the Male Gaze." Consumption Markets $\mathcal{E}$ Culture, vol. 5, 2002, pp. 231-246. 
Pawlak, Edward J., Maureen Skurski, Deborah Creamer, JoAnn Gundy, and Audrea Bishop.

"A View of the Mall." Social Service Review, vol. 59, no. 2, 1985, pp. 305-317.

Salazar, Joseph T. "Eating Out: Reconstituting the Philippines' Public Kitchens." Thesis Eleven, vol. 112, 2012, pp. 133-146.

Telci, Eser E. “High Shopping Mall Patronage: Is There a Dark Side?” Quality \& Quantity, vol. 47, 2013, pp. 2517-2528.

Tolentino, Rolando B. "Richard Gomez at ang Mito ng Pagkalalaki." Richard Gomez at ang Mito ng Pagkalalake, Sharon Cuneta at ang Perpetwal na Birhen, at Iba pang Sanaysay hinggil sa Bida sa Pelikula bilang Kultural na Texto, Anvil, 200o, pp. 13-29.

"Where \$26.92B of OFW Remittances Come from." GMA News Online, 9 June 20116, https://www.gmanetwork.com/news/money/content/500918/infographic-where-2692b-of-ofw-remittances-come-from/story/. Accessed 8 July 2016.

Wilwayco, Norman. Kung Paano Ko Inayos Ang Buhok Ko Matapos Ang Mahaba-haba Ring Paglalakbay. Automatic Writings, 2005.

Zosa, Victorina, and Aniceto Orbeta, Jr. "The Social and Economic Impact of Philippine International Labor Migration and Remittances." Philippine Institute for Development Studies (PIDS) Discussion Paper Series, 2009. 